\title{
Jawara and Local Election (Case Study of The Jawara Role of Tjimande Tari kolot Kebon Djeruk Hilir to win Wahidin Halim-Andika Hazrumy in the 2017 Banten gubernatorial election)
}

\author{
Saepudin, Kamaruddin \\ Department of Political Science \\ Faculty of Social and Political Science, UI \\ Depok, Indonesia \\ Saepudin.albantani88@gmail.com
}

\begin{abstract}
This research will explain about the history and role of the jawara in controlling Banten's economic, social and local resources.The influence of the Jawara increased in the beginning at the time of the Orde Baru who experienced social mobility into a powerful elite in Banten. In the reform era with the opening of community participation to make the jawara involved in supporting the candidate for local election in Banten.Jawara have a role and influence because they have magical powers and then control the economic resources that divert to the mastery of local politics.One of the jawara who is always involved in supporting candidates to the Banten region is the organization of TTKKDH jawara.The support of these jawara organizations is important because they have a wide and rooted structure from the center to the regions.In Banten local election 2017, TTKKDH supports Wahidin Halim-Andika Hazrumy to become Governor and Vice Governor of Banten. There are several roles of TTKKDH jawara, including as a supporter, facilitator, opinion leader, and successful team. In addition, there is a motivation of TTKKDH jawara that is normative and pragmaticopportunist.
\end{abstract}

Keyword-local election; jawara's role; traditional elite; power

\section{INTRODUCTION}

In 1998, with the fall of the Suharto regime for 32 years, the impact of changing the political order and governance in Indonesia was apparent. The fall was marked by the emergence of an era of reform that the government system is expected to be more fair, democratic and prosperous. The change of power also affects the relationship between the central and regional power structure with the enactment of regional autonomy. The basic idea of regional autonomy is; first, improving the service and welfare of the better society; second, to maintain a harmonious relationship between central and regional and inter-regional in order to maintain the unity of the Negara Kesatuan Republik Indonesia (NKRI); third, to develop the life of democracy, justice and equity (Leo Agustino, 2009: 26). Then democratization in Indonesia is marked by a free, fair and just general election as a form of the realization of human rights.

The main characteristic of the direct election of local election (Pilkada) is a shift in election voting pattern that elite vote to election model conducted by the community directly (popular vote). Some of the positive sides of the elections in the context of liberalization are political equality, local accountability, and local responses that are expected to arise community participation and improve the efficiency of local government (Amirudin and A.Zaini Bisri, 2006). However, the expansion of decentralization in developing countries is not always positively correlated with the strengthening of democracy and the efficiency of local governance structures. This is marked by the development of strong local people in the developing countries.

In Banten, there was a local strong man called jawara and was one of the dominant local forces, especially after the fall of the Orde Baru regime. The role of jawara actually can be traced historically when the archipelago under colonialism, where the jawara of many rebellions. In the early days of independence, the jawara were much involved in fighting for independence, then in the Orde Baru period, the jawara were coopted to support the government's development policies. During the Orde Baru, some jawara experienced social mobility because they went into the business world, such as contractors. The dominance of the economy in Banten because they controlled the Kamar Dagang Indonesia (KADIN), Lembaga Pengembangan Jasa Konstruksi (LPJK), and Gabungan Pengusaha Nasional Seluruh Indonesia (GAPENSI). While in politic local, they dominate and place their people in government both in the legislative and executive bodies.

Banten is actually a region dominated by two subcultures namely kyai and jawara who have influence in local politics both formal and informal. Initially the jawara and kyai were an 
inseparable entity, but with the dynamics and changing circumstances, especially when the Orde Baru, where kyai increasingly marginalized in politics and its role shifted to the informal role, while the formal role in the government dominated by many jawaras.

This research is interesting to be studied for several reasons. Firstly, research on jawara mostly examines the role of Chasan Sochib and his group as a local strongman of Banten. The implications of the role of jawara are identified with the role of Chasan Sochib and his group. Secondly, research on the role of jawara in direct elections is still rarely studied, especially in political perspective. Third, this research will focus on one of the mainstream martial arts in Banten, namely the Tjimande Tari Kolot Kebon Djeruk Hilir (TTKKDH) because this organization has political involvement and perhaps the most obvious in Banten (Gabriel Facal, 2016: 69). To understand the identity of the jawara, it is necessary to understand the organization that gave birth to the jawara because the jawara grow and develop through a series of life processes of the organization they live.

The TTKKDH organization has historically always been involved in the political dynamics of Banten. In Banten Local Election 2006 about 4,000 Banten people attended plenary meeting of DPP TTKKDH in Sayar Village, Taktakan Subdistrict. During the meeting, the organization through its representatives stated that they supported the Tryana Sjam'un and Benjamin Davnie as candidates for Governor and Vice Governor of Banten 2006. Although the support was not fully followed by TTKKDH senior elders who favored the couple Ratu Atut Chosiyah-HM Masduki. This indicates that the support of the TTKKDH organization is important as one of the factors to win every candidate in the Banten local election contest.

The support from TTKKDH becomes important and the seizure of every candidate Governor and Vice Governor of Banten. This is understandable because the organization is present in 15 provinces and the largest in Banten, Lampung, South Sumatra (Palembang), North Sumatra (Medan), Jakarta, West Java, East Kalimantan and Papua. In addition, there are several martial arts colleges abroad that are affiliated with TTKKDH as in Singapore, Australia, France, and the Netherlands. In terms of combustion, geographical distribution and the number of its members, TTKKDH is the main pillar of various governmental organizations controlling the socio- political situation, especially the organization of the Pendekar Banten (Gabriel Facal, 2016: 73).

In Banten Election 2017 the role of TTKKDH in supporting the candidates for governor and vice governor of Banten still shows its influence to be contested by the candidates. In this Banten pilkada which was followed by two pairs of candidates for Governor and Vice Governor of Banten 2017 ie couple Wahidin Halim-Andika Hazrumy and Rano karno-Embay Mulya Syarief. With only two candidates making the competition between candidates to be sharper. On Friday, September 16, 2016, TTKKDH jawara expressed his support to the candidate of Governor and Vice Governor Wahidin Halim-Andika Hazrumy, the support was officially delivered by DPP Chairman TTKKDH H. Maman Rizal in Serang Banten. According to Maman Rizal in Banten province, an active member of TTKKDH reaches 500 thousand people. This is confirmed by Toni as the Secretary of TTKKDH who said active members TTKKDH reach 500 thousand people and each member must follow the instructions of the chairman, the term when the chairman plunged then the members must follow. Also in TTKKDH there is an oath of loyalty or commonly referred to as partelekan as a rule for members of TTKKDH and obedience to the chairman.

Then there was support for Rano KarnoEmbay Mulya Syarief by dozens of uniformed masses of Satgas Kesenian Senit Tari (Kesti) TTKKDH who attended to enliven the special branch work meeting (Rakercabsus) DPC PDI Perjuangan Kota Cilegon, officially declared ready to escort Banten pilkada and became successful team Rano Karno-Embay Mulya Syarief. The result above can be concluded that the support from TTKKDH becomes important for every candidate of Governor and Vice Governor of Banten 2017 to win elections.

The involvement of TTKKDH in the Banten local election 2017 due to the history of the active and involved TTKKDH in every Banten local election. The success of this flow is partly due to the ability to develop networks and ensure subsistence for some of its members in the field of security or to strengthen their integration into networks of widespread and active influence in the field of entrepreneurship or politics (Gabriel Facal 2016: 74).

Based on the above explanation, this research will explain the role of jawara, especially TTKKDH champion in Banten local election 2017. The role is a daily term that everyone has a good role in the 
family, society, and other fields. The role is a dynamic aspect of a position (status). When a person exercises his rights and obligations in accordance with his position, the person carries out a role. So there is no role without position and position without role (Soerjono Soekanto, 2015: 213). Below is the definition of a role according to Ralph Linton:

"A role represents the dynamic aspect of status. The individual is socially assigned to a status and occupies it with relation to another status. When he puts the rights and duties with constitute the statuses into effect, he is performing a role. Role and status are quite inseparable, and the distinction between them is only academic interest. There are no roles without statuses or statuses without roles. Every individual has a series of the roles deriving from the various patterns, in wich he participates and at the same time a role in general, wich represents the sum of total of these roles and determines what he does for his society and what he can expect from i(Lewis A. Coser, 1964: 363)."

There are several components related to a role a person plays in society, namely a social position, role facilities, role-distance, and set of rules (Soerjono Soekanto , 2015: 213-214). A person is able to perform his role in society if it has role facilities. Jawara, in general, there is an institutionalized into a martial organization that has a place as an activity to practice the martial arts. The TTKKDH organization has a clear structure from the center to the regions.

To understand the role of individuals in society, it is necessary to understand the concept of Merton called role-set or role device. This concept explains that individuals have various roles that are incorporated and related to their status as well as with the roles and status of others. With a set of roles, a person or an individual is constantly in touch with others who also have certain role devices. For example, a teacher has an interactionist relationship with various parties in the school. The interaction can be with students, guardians, other teachers, school staff, and others.

How to understand TTKKDH jawara and its role in society can be explained by the concept. TTKKDH jawara have certain roles with their interactions with social subsystems of martial arts organizations or colleges, such as relationships with members of the university, with family members, surrounding communities, college elders, branches of the TTKKDH organization, other college organizations outside TTKKDH, unattached jawara with a particular college, community organization, political party organization, and other institutions

As an elite, jawara experience social mobility especially when the Orde Baru era, so that its influence becomes dominant and become a local elite in Banten. According to Pareto the elite are people who have the ability to be above the society, because they have the qualities needed for people's lives. Other experts such as Lipset and Solari explain that the elite are those who occupy positions in society at the top of the most important social structures, namely high positions in government economics, military, political, religious, teaching and jobs (JW Schrool , 1982: 128).

To become an elite is necessary sources of power. Charles F. Andrain defines power as the use of a number of resources (assets, abilities) to obtain compliance from others (Andrain, 1992: 130). While the source of power that consists of physical resources, economic, expertise, normative and personal. Jawara has a wider source of power because it involves the source of physical and economic power. With his magical and physical ability that sometimes becomes a tool to influence society. In addition, with the social mobility of champions, especially after a period of reform that controls various economic resources, making the jawara can take advantage of these factors to influence the community.

The ability of the jawara in dominating social, politic, and economy in Banten can not be separated from patron-client relationship. James C. Scott, defines patron-client as a reciprocal relationship between two roles which can be interpreted as a special case involving widespread resistance where one individual has a higher socioeconomic status (patron) the resources it has to provide protection or benefits to other individuals with lower status (clients), where clients have an obligation to retaliate by providing general support and assistance, including personal services to patrons.

Patron-client relationship forms can be in the form of a cluster ball (patron-client cluster) and pyramid pattern (patron-client pyramid). The cluster pattern is the form of a patron's relationship with some clients, while the pyramid pattern is a combination of several patron-client groups led by a patron as the highest patron. In a patron-client pyramid, a client of the highest 
patron is also a patron of several clients. Thus there are several small patrons who become the highest patron clients and have several clients themselves (Maswadi Rauf, 2001: 99).

Meanwhile, to know the motivation of the champions involved in politics, it is necessary to study the values and attitudes of the champions themselves. Gabriel A. Almond and Sidney Verba argue that political culture is a distinctly oriented attitude of citizens to the political system and its various parts and attitudes to the role of citizens in the system. Citizens always identify themselves with symbols and state institutions based on their own orientation (Almond and Sidney Verba, 1990).

There are three types of political culture. First parochial political culture, the political culture of individuals or societies who have absolutely no idea about or ignore the political issues surrounding them. For example, tribal peoples are alienated. Second, the subject's political culture, ie those who already have little information about politics, but no political stance, are easy to mobilize. They are passively obedient to government officials or politics and laws, without any capacity to evaluate. They are no further involved in political activities. Third, the political culture of participants, those who already have enough information and have the determination to act in political life. They engage in political activity, at least in voting.

\section{SOURCE OF POWER AND ROLE OF SOCIAL-POLITICS JAWARA}

In the development of history, the term of jawara has various versions because there is no historical evidence that explicitly records how or who the jawara. This is because the jawara themselves are born from ordinary people, not from the upper classes such as sultans, kings, nobles, and other leaders who are often recorded in history. The history of the jawara according to the researchers, can generally be traced to the rebellions that the people of Banten against the Dutch colonialism as a form of protest against the colonization that caused the suffering of the people.

According to Sartono Kartodirdjo, the class of jawara in general are people who do not have a steady job and often commit a crime (Sartono Kartodirdjo, 2015: 56). Meanwhile, according to Michael C. Williams, the term jawara itself refers to someone who is not only ready to oppose the laws and all kinds of legal rules that exist, but also against anyone in order to achieve their goals.
This group is found in rural Banten which is full of intrigue and is still developing (Michael C. Williams, 2003: 54). Jawara is a term in Banten for people who have martial arts skills and possess certain skills. In contrast to robbers and thieves, they are figures who are able to maintain the safety and security of the village, so that the community respects their existence. In general the jawaras are very obedient to the ulama because the spirit in their soul is obtained from the ulama. But there are some who behave negatively, but usually it can be overcome by their own colleagues.

Meaning that tend to be positive to the jawara delivered by Tihami, where the jawara become part of the people who have been educated in pesantren. The true jawara of kiai students who study the religious sciences in pesantren. In addition, they also explore the kanuragan sciences of the kiai, which ultimately becomes the preferred orientation developed. But the image of the jawara in the present tends to be negative, where some jawara prefer to identify themselves with the title of warriors.

Jawara as a person who has martial ability can not be separated from martial arts college as a place to train his ability. In Banten there are several martial arts including TjimandeTari Kolot Kebon Djeruk Hilir (TTKKDH), Jalak Rawi, Macan Paku Banten, Satria Muda Indonesia, Trumbu, Bandrong, Macan Guling, Gagak Lumayung, Si Pecut, Pustaka Tani, and others. In martial arts groups that form the basis of the formation of jawara, the youth are given a code of conduct by the organization. Among the code of ethics that should not be violated is, sirik (not to be jealous), pidik(should not spite), ujub (not to show off), and obedient to the leader. In addition there is a principle known miheulaan ulah (do not put attack first), kapiheulaan ulah (do not be attacked first). So they have a principle when facing the opponent is prohibited abstinence, because if a step back is considered infidel ( $k u f r$ ) (Priyono, 2004: 88).

In its development, the jawara are divided into two groups based on how to get the knowledge. First, the white wing champion (white magic) is a champion who uses the sciences of Islam as the main source of strength and used for good. Second, the black wing champion (black magic) is a champion who gained his strength not from the Islamic religion. The table below shows the difference of magic science based on black magic and white science which became the source of power of champion in Banten. 
Table 1

\begin{tabular}{|c|c|c|}
\hline Basic Typology & White Magic & Black Magic \\
\hline Source Authority & $\begin{array}{l}\text { Kyai (Science } \\
\text { of Wisdom) }\end{array}$ & $\begin{array}{l}\text { Dukun/Uran } \\
\text { g Pinter }\end{array}$ \\
\hline $\begin{array}{l}\text { Intention/Purpo } \\
\text { se }\end{array}$ & Goodness & Badness \\
\hline Ritual & $\begin{array}{l}\text { Practices of } \\
\text { worship such } \\
\text { as fasting, } \\
\text { memorizing } \\
\text { and reciting } \\
\text { Qur'anic } \\
\text { verses as a } \\
\text { bargain for } \\
\text { the soul of } \\
\text { people } \\
\text { seeking } \\
\text { knowledge / } \\
\text { getting help }\end{array}$ & $\begin{array}{l}\text { Objects } \\
\text { sometimes } \\
\text { accompanied } \\
\text { by mixed } \\
\text { mantras } \\
\text { (jangjawokan } \\
\text { J and verses } \\
\text { of the Qur'an }\end{array}$ \\
\hline Magic Item & $\begin{array}{l}\text { It tends to be } \\
\text { nonexistent, } \\
\text { just a rote } \\
\text { that needs to } \\
\text { be mentioned } \\
\text { both } \\
\text { periodically } \\
\text { as strictly as } \\
\text { it is done } \\
\text { when it will } \\
\text { be necessary. }\end{array}$ & $\begin{array}{l}\text { It tends to be } \\
\text { nonexistent, } \\
\text { just a rote } \\
\text { that needs to } \\
\text { be } \\
\text { mentioned } \\
\text { both } \\
\text { periodically } \\
\text { as strictly as } \\
\text { it is done } \\
\text { when it will } \\
\text { be necessary. }\end{array}$ \\
\hline Requirements & $\begin{array}{l}\text { The purity of } \\
\text { the soul in } \\
\text { the form of } \\
\text { formal } \\
\text { worship, and } \\
\text { away from } \\
\text { acts that } \\
\text { violate } \\
\text { religion. } \\
\text { Usually } \\
\text { begins with } \\
\text { the } \\
\text { fulfillment of } \\
\text { certain ritual } \\
\text { forms of } \\
\text { worship such } \\
\text { as congregation } \\
\text { congrayer, } \\
\text { al prast } \\
\text { fasting, wirid } \\
\text { in the amount } \\
\text { specified. }\end{array}$ & $\begin{array}{l}\text { Sometimes it } \\
\text { takes certain } \\
\text { requirement } \\
\text { s such as } \\
\text { fasting for } 7 \\
\text { consecutive } \\
\text { days, but it is } \\
\text { generally a } \\
\text { talisman that } \\
\text { can be } \\
\text { summoned } \\
\text { with a } \\
\text { certain } \\
\text { mantra or } \\
\text { intention. }\end{array}$ \\
\hline Science for users & $\begin{array}{l}\text { Tend to long- } \\
\text { term }\end{array}$ & $\begin{array}{l}\text { Tend to } \\
\text { short-term }\end{array}$ \\
\hline
\end{tabular}

purposes. purposes.

Resource: Priyono, "Lurah, Kyai dan Jawara: Kepemimpinan Banten di Desa Senangsari Kabupaten Pandeglang", Tesis, Departemen Antropologi Program Pascasarjana Antropologi Fakultas Ilmu Sosial dan Ilmu Politik Universitas Indonesia, Depok, 2004

Jawara have a social role in Banten society, because they have abilities that are not owned by society in general, so they tend to be followed. According to Mohammad Hudaeri, the social roles of the champions are as follows (Mohammad Hudaeri, 2002):

- Jaro

Jaro or commonly called the village chief who leads a village. At the time of the sultanate jaro was appointed by the sultan with his main task was to take care of the interests of the sultanate, such as picking up tribute and deploying labor for consecrated work. In the course of daily work, jaro is assisted by other officials such as drawer (jaro secretary), jagakersa (security department), pancalang (regulator letter), amil (tax collector and tax), merbot or modin (religious affairs and mosque).

- Silat Teacher

In pre-Islamic times has been known term perguron or padepokan in the area around Gunung Karang, Pandeglang. In the society of Banten known various perguron or martial organization, such as Terumbu, Bandrong, Paku Banten, Jalak Rawi, Cimande, Si Pecut and so on. Each peguron has characteristics in the stance and history of its birth.

- Magical Teacher To be a famous jawara must be supported by good martial arts and have inner or magical knowledge, ie the ability to manipulate supernatural powers and to meet his practical needs, such as immune from various sharp weapons, fireproof, predatory, exorcist jinns and demons, spiritual control and treatment, such as broken bones and masseuse. The forms of elves that are often used by the jawara are brajamusti (the ability to do a great blow), ziyad (controlling something from afar), talisman or tattoo to seek authority, wealth or 
beloved, putter gilling (to rewind or rediscover the person lost or blurred), elmu (to conquer a venomous or dangerous animal) and so on.

- Debus Players

The role of jawara who is still close to the miracle is a game of debus. Debus game is mostly done by the jawara, who are considered to have enough magic. So not all jawara can do debus game, because for those who can not afford it will bring disaster or accident. In Banten there are several kinds of debus, namely debus al-madad, surosowan and langitan. Named the debus of al-madad (meaning asking for help and help) because the players every time do the action always say almadad words, which seemed to illustrate that this action is based on the help of Allah SWT. Debus al-madad is the greatest debus because to perform this game his khalifah (group leader) must perform a very long and heavy deed. These khalifah debus deeds are taken from the Rifa'iyah or Qodariyah.

\section{- Kyai Khodim}

The real jawara is kiai khodim. The role of kiai khodim means to play the role that the kiai teaches, that is to defend the truth, to side with the weak, polite and not arrogant behavior and a number of other normative rules. The ideal roles are rarely performed by the jawara in the midst of a materialistic life.

While the role of jawara in the reform period can be seen at the Banten local election in 2001 which is still selected by the DPRD. In this election the jawara have the influence to win the candidates they hold. In the election there is a famous jawara boy who will progress to Vice Governor of Banten, namely Ratu Atut Chosiyah. Previously Ratu Atut Chosiyah mostly run the company business of his parents namely PT. Sinar Ciomas Group. According to Boyke Personal lecturer University of Tirtayasa (Untirta), "Golkar supports Atut is inseparable from the great role of his father, Jawara. He is a character who is considered to have many services to Golkar "(Lili Romli, 2007: 143). This is understandable because the prominent figure became a supporter of the Orde Baru and participated in securing government policies at that time.
Support jawara against Ratu Atut Chosiyah can be seen from the support organization of Persatuan Pendekar Persilatan dan Seni Budaya Banten Indonesia (PPPSBBI) submitted on September 18, 2001. PPPSBBI itself is chaired by a prominent figure who is none other than the parents of Ratu Atut Chosiyah. Support PPPSBBI in the form of a letter shown directly to the Governor and Vice Governor Election Committee of Banten. The existence of the letter indicates several things between them. Firstly, the letter of support has explicitly given a signal about the alignment of the winner against the candidate for Vice Governor Ratu Atut Chosiyah, and whoever the candidate for governor who will be paired with the concerned. Secondly, the letter also reflects one of the earliest forms of involvement of the jawara in the election process of the Governor and Vice Governor (Lili Romli, 2007: 151).

The involvement of the jawara in the Banten local election 2001 was seen with involvement in the form of mass mobilization. The jawara also intimidate candidates and supporters of candidates for certain Governor-Vice Governor candidates. Furthermore, in the form of securing the election by mobilizing its mass to secure the DPRD building. As a concrete form of support of Tokoh Jawara against the partner he was sitting on, he sat in the sitting seat of the VIP invitation. In addition, the support of jawara is inseparable from the motivation to master economic resources (Lili Romli, 2007: 151-153).

The results of research conducted by Abdul Hamid in assessing the role of group winners in supporting Djoko-Atut in the election of Governor and Wail Governor of Banten period 2001-2006. The findings of this study are champions as a strategic group doing two strategies. First, by hybridization, the expansion of the takeover into new areas by utilizing new sources of income. Then Golkar get support from the jawara and bring opportunities for winners to get development projects. Second, by way of coalition that is building cooperation with various strategic groups, government and military institutions. The position of the jawara is strong because they control the sources of power such as economic resources, means of coercion, personal charisma and organized masses. In the election of the Governor of Banten in 2001 the jawara of the rawu group had role as follows. First, the winner wins the internal battle of Golkar regarding the position to be taken and who will be submitted. Second, take the PPP as 
the main coalition partner. Third, intimidation by mobilizing the power of the masses. Fourth, doing money politics. Fifth, the control of opinion (Abdul Hamid, 2004).

Then in the elections of the Governor and Vice Governor of Banten 2006 which directly conducted by the community, the jawara were reinvolved in the support of the spouses of the governor and the deputy governor. In the election there are four pairs of candidates set KPUD namely Tb. Tryana Sjam'un-Benyamin Davnie, Ratu Atut Chosiyah-HM. Masduki, Irsyad DjuweliMas Achmad Daniri, and last ZulkiflimansyahMarissa Haque. Each pair of candidates is supported by a jawara, either from a jawara who has been organized in an organization or jawara who does have the personal ability to follow. The table below shows the support of the jawara to each candidate pair of Governor and Vice Governor in Banten local election 2006.

Tryana Sjam'un-Benjamin Davnie is supported by a jawara TTKKDH who is one of the jawara organization that has a wide network in Banten and rooted. Individual jawara is supported by Buya Karis, Apih July who was previously a member of the Volunteers of Banten Bersatu (RBB), H. Suraka as a lot of poor jawara across Jakarta. Ratu Atut Chosiyah couples are also supported by TTKKDH especially the dedengkot (pini sepuh). In addition the couple is supported by PPPSBBI which is a leader organization leader of Jawara. Couples Zulkiflimansyah-Marissa Haque and Irsyad Juseli-A Daniri not so much supported jawara like the other couple. Among the couples who support Zulkiflimansyah-Marisa Haque is Sudirman, other than that the jawara who are affiliated to the PDIP also support Marissa's campaign (Lili Romli, 2007: 179-188).

Based on the perspective of elite theory where the jawaras are people who have the ability to be above other societies because the jawara have the ability of magic, courage, martial arts. In additional they occupy the top position due to social mobility and control of economic resources, government, and have good relations with security forces such as police and soldiers.

Jawara has the ability to mobilize patronclient relations among fellow jawara due to material dependence. Jawara figures as the Banten elite master the various economic resources so many who patron to him. While the relationship jawara with the ruler is more symbiotic mutualism because the jawara need the support of the ruler to defend his interests, while the ruler needs support jawara as one factor to win back in the election of leaders in Banten.

\section{MOTIVATION AND THE ROLE OF TTKKDH IN SUPPORTING WAHIDIN HALIM-ANDIKA HAZRUMY}

In the previous discussion explained about the political role of the jawara, especially in every local election which started in 2001, the electoral mechanism is still conducted by the DPRD, then proceeded to pilkada conducted directly by the community. Based on the description, the jawara $\mathrm{s}$ are always involved in supporting the support of candidate pair of Governor and Vice Governor of Banten because they have influence and social identification which followed by society, besides to maintain various resources, economic, social and political. One of the Jawara organization which is often involved in the dynamics of Banten regional head elections is the organization of TTKKDH and in Banten election 2017 supports the couple Wahidin Halim-Andika Hazrumy.

There are several political roles jawara TTKKDH in supporting candidate pair of Governor and Vice Governor of Banten Wahidin Halim-Andika Hazrumy in Banten local election 2017 of them:

First, Supporters. Jawara TTKKDH in the interaction did not close the relationship and friendship with the candidate of the governor and deputy governor Wahidin Halim-Andika Hazrumy and Rano Karno-Embay Mulya Syarief. Any candidate for a candidate for governor of Banten who wants to make a relationship with TTKKDH will be welcomed. However, in the process TTKKDH support was given to the Wahidin Halim-Andika Hazrumy, this was revealed by Fitron Nur Ikhsan as the person involved in the winning team of Wahidin HalimAndika Hazrumy, where the declaration of TTKKDH support was given at Ratu Serang Hotel Banten. As an old and deeply rooted organization in Banten, the declaration indirectly also gives direction to TTKKDH members who are in the regions to follow the leader's instructions.

Second, Facilitator. As an official martial organization in Banten, TTKKDH has a secretariat, paguron or a place to teach martial arts to its members. Paguron is a place to facilitate candidates who want connect and ask for support to TTKKDH. Andika Hazrumy as a candidate for vice governor of Banten 2017 has visited the secretariat of TTKKDH, and the result of the visit is the support from TTKKDH to the couple Wahidin Halim-Andika Hazrumy. TTKKDH 
itself opens opportunities for anyone to connect, but more supportive couple Wahidin HalimAndika Hazrumy. Jawara as a facilitator because it has role facilities (role facilities) in the form of Hermes from center to areas in Banten.

Third, the Opinion. Jawara as one of the subcultures in Banten because it has advantages of ordinary people, however, have the influence of opinion leaders. In addition, TTKKDH has branches up to the area to be followed by each member. In the organization of the jawara TTKKDH there is a pledge or oath of allegiance called partelekan, where every member or student of TTKKDH must follow instruction or election from the chairman. When the head of TTKKDH H. Maman Rizal gives choice and support to the couple Wahidin Halim-Andika Hazrumy then automatically every member or student of TTKKDH must follow the direction. One of the reasons TTKKDH jawara to give support to the couple Wahidin Halim-Andika Hazrumy because of their leadership character according to what is outlined by TTKKDH. Although the relationship of a champion with the jawara there are elements of the material, in TTKKDH there is another element called as partelekan. With partelekan members of the champion must follow what is ordered by the chairman, so that patron-client relationship is not always a material element. Jawara TTKKDH in the community has the advantage of often holding art events such as debus, so it is considered to have more ability than the public in general, and with these advantages, they become the elite who followed his opinion by the people.

Fourth, Team Success. Another role performed by TTKKDH is a successful team. There are various forms performed by successful teams to win Wahidin Halim-Andika Hazrumy candidates such as campaigning, mobilizing the masses, or engaging in other activities. Based on the information that the authors obtained from some sources, it is known there are members of TTKKDH who later became a successful team in winning the couple Wahidin Halim-Andika Hazrumy. By becoming a successful team, TTKKDH members become active in campaign activities and other related activities to win the spouses they support.

Support of TTKKDH jawara to Wahidin HalimAndika Hazrumy driven various motives, ranging from the normative and the pragmaticopportunistic. Normative because of the support they give to the couple Wahidin Halim-Andika Harzumy because of their character that is in accordance with TTKKDH. While the pragmatists because in its history especially since the Orde Baru came to power, TTKKDH tended to support Golkar. Support to the ruling regime caused the winner or TTKKDH to always be a member of the board. In Serang City itself, there are indications of some parking lots and security coordinated by TTKKDH, so that with the support of the ruler can provide the existence of the roles of TTKKDH jawara in the mastery of several economic sources. There are three political cultures: parochial, subject, and participant. TTKKDH jawara in politics falls into the category of participant's political culture because they have been actively involved in local politics since the Orde Baru and often its members get positions in government.

\section{REFERENCES}

Agustino, Leo (2011). Pilkada dan Dinamika Politik Lokal. Yogyakarta: Pustaka Pelajar.

Abdul Hamid, "Peran Jawara Kelompok Rawu terhadap Kemenangan Pasangan "DjokoAtut" dalam Pemilihan Gubernur dan Wakil Gubernur Banten Periode 2001-2006", Skripsi, Program Sarjana Departemen Ilmu Politik Fakultas Ilmu Sosial dan Ilmu Politik Universitas Indonesia, Depok, 2004.

Almond dan Sidney Verba. (1990). Budaya Politik, Tingkah Laku Politik dan Demokrasi di Lima Negara (terj. Sahat Simamora), Jakarta: Bumi Aksara,

Amirudin dan A. Zaini Bisri. (2006). Pilkada Langsung Problem dan Prospek Sketsa Singkat Perjalanan Pilkada 2005, Yogyakarta: Pustaka Pelajar.

Andrain. (1992). Kehidupan Politik dan Perubahan Sosial, Yogyakarta: Tiara Wacana

Coser, Lewis A. dan Bernard Rosenberg. (1964). Sociological Theory, A Book of Reading, The New York: Macmilan Company.

Facal, Gabriel. (2016).Keyakinan dan Kekuatan Seni Bela Diri Silat Banten, Jakarta: Yayasan Pustaka Obor Indonesia.

Kartodirdjo, Sartono. (1984). Pemberontakan Petani Banten 1888, Jakarta: Pustaka Jaya. 
Lili Romli, "Jawara dan Penguasaan Politik Lokal di Provinsi Banten (2001-2006)", Disertasi, Departemen Ilmu Politik Program Pascasarjana Fakultas Ilmu Sosial dan Ilmu Politik Universitas Indonesia, Depok, 2007.

Mohammad Hudaeri, "Tasbih dan Golok: Studi Tentang Kedudukan, Peran dan Jaringan Kyai dan Jawara di Banten", Laporan Penelitian, Serang: Sekolah Tinggi Agama Islam Negeri Sultan Maulana Hasanuddin Banten, 2002.

Priyono, "Lurah Kyai dan Jawara: Kepemimpinan Banten di Desa Senangsari Kabupaten Pandeglang", Tesis, Departemen Antropologi Politik Program Pascasarjana Fakultas Ilmu Sosial dan Ilmu Politik Universitas Indonesia, Depok, 2004.
Rauf, Maswadi. (2001). Konsensus dan Konflik Politik, Jakarta: Direktorat Jenderal Pendidikan Tinggi, Depdiknas,

Schoorl, J.W. (1982). Modernisasi; Pengantar Sosiologi Pembangunan Negara-Negara Sedang Berkembang, Jakarta: Gramedia,

Soekanto, Soerjono. (2015). Sosiologi Suatu Pengantar, Jakarta: Raajwai Pers

William, Michael C. (2003). Arit dan Bulan Sabit: Pemberontakan Komunis 1926 di Banten, Yogyakarta: Syarikat 